\title{
A BOCSÁNATKÉRÉS ÉS A JÓVÁTÉTEL HATÁSA A MEGBOCSÁTÁSRA KÖZELI ÉS TÁVOLI KAPCSOLATOKBAN
}

\author{
PAPP GÁBOR - KOVÁCS JUDIT
}

DE BTK Pszichológiai Intézet, Szociál- és Munkapszichológiai Tanszék

E-mail: papp.gabor@arts.unideb.hu; kovacs.judit@arts.unideb.hu

Beérkezett: 2014. október 10. - Elfogadva: 2014. december 20.

\begin{abstract}
Jelen tanulmányban két vizsgálatot ismertetünk, amelyeknek az volt a célja, hogy feltárja a bocsánatkérés és a jóvátétel megbocsátásra gyakorolt hatását. Az elsö vizsgálatunkban egy nem túl nagy volumenü sérelmet követöen egy nem túl szoros kapcsolatban szcenáriós és laboratóriumi vizsgálatban ellenöriztük, hogyan segitheti a jóvátétel a megbocsátást. A második vizsgálatunk felidézéses jellegü volt, arra kértük a vizsgálati személyeket, hogy írjanak le egy nehezen megbocsátható sérelmet. Eredményeink szerint a jóvátétel segithet egy sérelmet megbocsátani. A jóvátétel hatékonyságát befolyásolja, hogy a jóvátételről szóló döntést ki hozza meg: a jóvátételről intézményes keretek között született döntés hatásosabb, mint ha a jóvátételröl maga az elkövetö dönt, legalábbis kis volumenü sérelmek esetében, nem túl szoros kapcsolatban. A jóvátétel közeli kapcsolatban is segítheti a megbocsátást, de egy sérelmet követöen a kapcsolat teljes helyreállításában a bocsánatkérést nem pótolja, mindkét viselkedésnek megvan a maga szerepe. A jóvátétel elsősorban a megbocsátást segíti a sérelem negativ következményeinek enyhitése révén, a bocsánatkérés pedig a kapcsolatok helyreállását közvetlenül segíti elö.
\end{abstract}

Kulcsszavak: megbocsátás, jóvátétel, bocsánatkérés, közeli és távoli kapcsolatok

\section{BEVEZETÉS}

Kellemetlen érzés megtapasztalni azt, amikor megbántanak minket. Ilyenkor úgy érezzük, hogy diszkrepancia van a között, ahogy a dolgoknak lenniük kellene, és ahogy ténylegesen vannak (Exline, WORTHINGTON, Hill és MCCullough, 2003). Úgy érezzük, hogy igazságtalanság áldozatai lettünk. Egy ilyen helyzetben 
jellegzetes reakció, ha a sértett fél az igazság helyreállítására vágyik (DARLEY és PitTMAn, 2003), amelynek lényege, hogy a sértő felet érje valamilyen büntetés az általa elkövetett sérelmekért (STRELAN, FEATHER és MCKEE, 2008).

Az elmúlt húsz évben egyre nagyobb figyelmet kapott egy másfajta, sérelmet követő reakció vizsgálata, a megbocsátásé (STRELAN és mtsai, 2008, FInCHAM, 2009). Kezdetben a megbocsátásra úgy tekintett a szakirodalom, amely révén az elkövető mentesül tettének következményei alól (FincHAM, 2009). Így a megbocsátó sértett fél lemond arról a jogáról, hogy a sérelemért elégtételt vegyen, ami ellentmondhat az igazságérzetnek (KARREMANS és VAN LANGE, 2004).

Az utóbbi időben azonban megerősödött az a felfogás, amely szerint a megbocsátás és az igazságosság összeegyeztethetőek (lásd például STRELAN és mtsai, 2008; Fincham, 2009). EXLINE és munkatársai (2003) szerint az igazságérzet helyreállása komoly szerepet játszhat egy sérelem megbocsátásában. Bizonyos procedurális és disztributív igazságosságelemek pedig megjelenhetnek a megbocsátás prediktoraiként is. Jelen tanulmányban elsősorban a jóvátétellel és a bocsánatkéréssel fogunk foglalkozni mint ilyen igazságosság elemmel. Két vizsgálatban mutatjuk be, hogy hogyan segíthetik elő az interperszonális megbocsátást és a felek közötti kapcsolat rendezését.

\section{A megbocsátás meghatározása}

A megbocsátásra adott számos definíció talán legfontosabb közös eleme a sérelmet okozóval kapcsolatos negatív érzések, gondolatok, viselkedések redukciója. Az azonban vitatott, hogy vajon ez elég-e ahhoz, hogy megbocsátásról beszélhessünk, vagy szükséges-e ezen túl valamilyen pozitív érzésnek, gondolatnak, viselkedésnek a megjelenése is (MCCullough, PARGAMent és ThORESEN, 2001)?

WORTHINGTON (2005) úgy érvel, hogy ha figyelembe vesszük a kapcsolatot, amelyben megtörtént a sérelem, akkor feloldható ez a dilemma. Távoli kapcsolatban a sérelem okozta negatívumok megszűnése egyenértékű lehet a megbocsátással, ugyanakkor egy szorosabb kapcsolat esetében a negatívumok megszünését nem éljük meg a megbocsátással egyenértékűnek. Éppen ezért, amikor a megbocsátásról beszélünk, az adott körülményekhez és a kapcsolathoz kell igazítanunk azt, mit tekintünk megbocsátásnak.

Ezek alapján a megbocsátást a következőképpen határozzuk meg: a megbocsátás egy sérelmet követően játszik szerepet (FINCHAM, 2009), és egy olyan megküzdési mechanizmus, amelynek célja a distressz enyhítése (WORTHINGTON és SCHERER, 2004), a negatívumok redukciója. Ha pedig a felek közötti kapcsolat lehetővé teszi (WORTHINGTON, 2005), akkor a megbocsátás révén felerősödhetnek a pozitív érzések, gondolatok, motívumok is, amelyek aztán kapcsolatépítő viselkedésekhez és a kapcsolat fennmaradásához vezetnek. 


\section{Jóvátétel és bocsánatkérés}

A megbocsátást számos tényező befolyásolhatja. FeHR, GELFAND és NAG (2010) szerint a szituatív tényezők nagyobb szerepet játszanak egy sérelem megbocsátása során, mint a személyiségtényezők, de természetesen a személyiségjellemzők szerepe is jelentős.

Jelen tanulmányban két helyzeti tényezőre, a jóvátételre és a bocsánatkérésre fogunk koncentrálni. A jóvátétel olyan viselkedés, melynek a célja a sérelem következtében felboruló egyensúlyi helyzet helyreállítása (FEHR és GELFAND, 2010). A disztributív igazságossággal foglalkozó szakirodalomból ismert, hogy az emberek számára fontos a különböző erőforrások kiegyensúlyozott eloszlása. A jóvátétel az ilyen egyenetlenségeket hivatott kiegyenlíteni. A jóvátétel kifejezés prototipikusan anyagi, megfogható jellegű kárpótlást feltételez, de társas-érzelmi megnyilvánulásai is vannak. Például ha egy értekezlet egyik résztvevője ellenséges módon viselkedett és ezzel sérelmet okozott, társas-érzelmi jóvátételként viselkedhet úgy, hogy fokozott mértékű tiszteletet tanúsít munkatársai és főnöke iránt a következő értekezlet alkalmával (FEHR és GELFAND, 2010).

RisTOVSKI és WERTHEIM (2005) szerint a jóvátétel forrása meghatározza annak a hatékonyságát. Vizsgálatukban összevetették az elkövető által önkéntesen felajánlott jóvátételt, az elkövető által kényszer hatására fizetett jóvátételt, illetve egy külső forrás által megítélt jóvátételt. A leghatékonyabbnak az önkéntes jóvátétel bizonyult. Ebben az esetben a sérelmet elszenvedő fél azt tapasztalja, hogy a másik törekszik az általa okozott sérelem tompítására. Ha a sérelmet elszenvedő felet egy külső forrás (például egy kormányzati szerv) kárpótolja, akkor helyreáll az egyensúlyi helyzet, de ez nem a sérelmet okozó fél erőfeszítéseinek köszönhető. RISTOVSKI és WERTHEIM (2005) eredményei közül kiemelendőnek tartjuk, hogy a külső forrásból érkező kárpótlás jótékony hatása volt a második legerőteljesebb, ami azt implikálja, hogy egy külső forrásból származó jóvátétel szükség esetén segítheti a megbocsátást.

A bocsánatkérés során a sértő fél kifejezésre juttatja a felelősségét és bűntudatát, és elhatárolódik korábbi tettétől (LEunissen, DE Cremer, Folmer és vaN DIJKE, 2013; SCHER és DARLEY, 1997). Implicit módon tartalmazza azt az ígéretet, hogy a sérelem nem fog megismétlődni (KIM, DiRKs, és COOPER, 2009). Ezzel az elkövető jelzi, hogy megbízható, és a kapcsolat folytatása a sértett fél számára nem jelent kockázatot (Haesevoets, Reinders Folmer, DE Cremer, és VAN Hiel, 2013). Figyelemre méltó, hogy a bocsánatkérés nem a sérelem okozta károk rendezését célozza, mégis hatékonyan segítheti a megbocsátást és a kapcsolat rendeződését (FISCHBACHER és UTIKAL, 2013).

\section{AZ 1. VIZSGÁLAT}

Jelen tanulmányban két vizsgálatot mutatunk be. WORTHINGTON (2005) nyomán úgy véljük, hogy a megbocsátást érdemes szorosabb és kevésbé szoros kapcsolatokban eltérő módon értelmezni. Emiatt az első vizsgálatban egy nem túl szoros 
kapcsolatban vizsgáltuk a fent említett procedurális és disztributív igazságosságelemek hatását, míg a második vizsgálatunkat úgy terveztük meg, hogy a hatások szorosabb kapcsolatban is ellenőrizhetők legyenek.

\section{Hipotézisek}

H1: A teljes jóvátétel hatékonyabb, mint a részleges jóvátétel, ami hatékonyabb, mint a jóvátétel hiánya.

H2: Jobban segíti a megbocsátást, ha a jóvátételről az elkövető dönt, mintha egy külső intézményes szabályozás rendelkezne róla.

H3: A második hipotézisben feltételezett főhatás erősebb pozitív, mint negatív jóvátételi döntés esetén, de ha a jóvátételi döntés nemleges, az intézményes háttér tompíthatja a személyes csalódottságot.

\section{Alanyok és eljárás}

Első vizsgálatunkban az adatokat kétféle módszerrel gyűjtöttük. Az első lépésben egy szcenáriós vizsgálatot folytattunk le, amelyhez az adatokat kérdőíves módszerrel gyűjtöttük. A második lépésben az első vizsgálatban vázolt szituációt megvalósítottuk laboratóriumi körülmények között, és felmértük, hogy a vizsgálati személyek ténylegesen hogyan viselkedtek abban az adott helyzetben.

A kérdő́ives adatgyưjtésben 323 fö vett részt, 229 nő és 92 férfi (2 személy nem válaszolt erre a kérdésre). A vizsgálatban 19 és 35 év közötti, átlagosan 22,38 éves személyek vettek részt. Az adatgyüjtés önkéntes alapon, névtelenül zajlott.

A laboratóriumi vizsgálatban a vizsgálati személyeket egy diákmunkával foglalkozó szervezet segítségével toboroztuk. A vizsgálatban 117 fő vett részt, 61 nő és 56 férfi. A vizsgálati személyek 17 és 28 év közöttiek voltak, az átlagéletkor 21,6 volt. A vizsgálati személyek a részvételükért 1200 Ft-os díjazásban részesültek, melyhez a vizsgálat során további összegeket nyerhettek (ennek mértéke átlagosan 470 Ft volt). A vizsgálat egymástól elszeparált számítógépek mögött zajlott, menete a lehetőségekhez képest megegyezett a kérdőíves adatgyüjtéssel.

\section{Módszer}

\section{A független változók manipulálása a kérdőíves vizsgálatban}

A vizsgálati személyek egy szituációt olvastak, amelyben manipuláltuk a független változókat. A szituációban a vizsgálati személyeknek el kellett képzelniük, hogy részt vehetnek egy játékban, amelyben pénzt lehet nyerni, ám az utolsó pillanatban egy, a játékostársak közül véletlenszerủen kiválasztott személy miatt kimaradnak belőle. Ezek után megtörtént a jóvátételi manipuláció. A jóvátétel a következőképpen alakulhatott: a vizsgálati személy nem kap semmilyen jóvátételt; a 
vizsgálati személy anyagi kárpótlást kap, de nem próbálhatja ki a játékot; a vizsgálati személy kipróbálhatja a játékot, de nem kap anyagi kárpótlást; és végül a vizsgálati személy anyagi kárpótlást is kap, és a játékot is kipróbálhatja.

A második és a harmadik helyzetben látható, hogy csak részleges jóvátételről van szó, míg a negyedik helyzetben a jóvátétel teljes körủ. A második és a harmadik helyzetet az elemzések során összevonva kezeltük, részleges jóvátételi helyzetként. Az összevonást az indokolta, hogy a jóvátétel mindkét helyzetben hasonló jellegű sérelmet, valamilyen nyereség elvesztését kompenzálja, az egyik az élvezet okozta öröm, a másik a pénz okozta öröm elvesztését. Lényeges, hogy egyiknek sincs erkölcsi rehabilitációs mozzanata. DE CREMER (2010) rámutatott arra, hogy a különböző jellegű sérelmek (nyereség elvesztése vagy veszteség elszenvedése) esetében különböző módon működhet a jóvátétel és a bocsánatkérés, így ha a sérelem jellege más lett volna, ez az összevonás nem lenne elvégezhető. Az elemzéseink továbbá nem mutattak szignifikáns különbséget a második és a harmadik jóvátételi helyzet között egyetlen vizsgált függő változó esetében sem (erről bővebben az Eredmények bemutatása pont alatt szólunk), így indokoltnak láttuk az eredmények egybevont, részleges jóvátételi helyzetként történő bemutatását.

A szituációkban manipulált változók alapján így egy $3 \times 2$-es elrendezés alakult ki, a jóvátétel három esetének (nincs jóvátétel, részleges jóvátétel van, teljes jóvátétel van) és a jóvátételi döntést hozó alany két esetének (elkövető, intézmény) kombinációi. Az egyes csoportokba a vizsgálati személyek véletlenszerűen kerültek be. A teljes jóvátételt kapó, illetve a semmilyen jóvátételt nem kapó csoportokba megközelítóen 40-40 személy került, akár az elkövető hozta a jóvátételi döntést, akár az intézmény, míg a részleges jóvátételt kapó csoportokba 80-80 személy, 40 olyan, aki anyagi kárpótlást kapott, de nem kapott élménykárpótlást, illetve 40 olyan, aki élménykárpótlást kapott, de nem kapott anyagi kárpótlást (a szituáció bemutatását lásd részletesebben a következő szakaszban).

\section{A független változók manipulálása a laboratóriumi vizsgálatban}

Hasonlóan a kérdőíves adatgyűjtéshez, egy $3 \times 2$-es elrendezés alakult ki, de itt a résztvevők ténylegesen átélték a helyzetet. A vizsgálati személyek úgy tudták, hogy ők voltak a kizárt személyek. Az egyes jóvátételi csoportokba a vizsgálati személyek véletlenszerűen kerültek be. A vizsgálatot egy játékos feladat zárta, melynek célja az esetleges kialakult feszültségek csökkentése volt.

Megközelítően 15-15 személy került a teljes jóvátételt kapó, illetve a semmilyen jóvátételt nem kapó csoportokba, akár az elkövető hozta a jóvátételi döntést, akár az intézmény, míg a részleges jóvátételt kapó csoportokba 30-30 személy, 15 olyan, aki anyagi kárpótlást kapott, de nem kapott élménykárpótlást, illetve 15 olyan, aki élménykárpótlást kapott, de nem kapott anyagi kárpótlást.

\section{Érzelmi állapotot mérő skála}

A szituációt követően a vizsgálati személyeknek meg kellett ítélniük öt érzelempár vonatkozásában, hogyan éreznék/érzik magukat abban a helyzetben, amit a szituá- 
cióban olvashattak, vagy amibe a kísérleti helyzetben kerültek. Az öt érzelempár a következő volt: szomorú - vidám, zaklatott - higgadt, értetlen - megértő, feszült oldott, lehangolt - derűs. A vizsgálati személyek 7 fokú skálán jelölték, melyik érzelem jellemzi őket. Az öt érzelempárt egybevontuk, és egy olyan mutatót képeztünk, amely kifejezi, mennyire éreznék magukat kellemetlenül vagy kellemesen a vizsgálati személyek. A magasabb pontszám pozitívabb érzéseket, az alacsonyabb pontszám negatívabb érzéseket takar. A Cronbach- $\alpha$ mutatója ennek a skálának 0,86 .

\section{Megbocsátás Skála}

A helyzeti megbocsátás méréséhez a RYE és munkatársai (2001) által kidolgozott „Megbocsátás Skála” (,Forgiveness Scale”) PAPP és munkatársai (2014) által módosított változatát használtuk. Az eredeti skála 15 itemet tartalmaz, amelyek két faktorba csoportosíthatók. Az első faktor a Negatívumok Hiánya (Abscence of Negative, pl. „Képes lennék arra, hogy az iránta érzett haragomat elengedjem.”) a második faktor a Pozitívumok Jelenléte (Presence of Positive, például ,Jó dolgokat kívánok neki.") nevet viseli. Ez a két faktor magában foglalja egyrészt a negatív érzések, gondolatok, motívumok hiányát, másrészt a pozitív érzések, gondolatok, motívumok jelenlétét is.

A skála módosított változatából hiányoznak azok az állítások, amelyek nagyon erőteljes kifejezéseket tartalmaznak, például „Azt hiszem, az életemet tönkretette ez az ember”. Egy viszonylag enyhe sérelem esetében, kísérletes helyzetben ezeknek az itemeknek az alkalmazása nem indokolt. Vizsgálatunkban a két skála Cronbach- $\alpha$ megbízhatósági mutatója jónak mondható (Negatívumok Hiánya: 0,86; Pozitívumok Jelenléte: 0,84 ).

\section{Eredmények}

\section{A skálák közötti összefüggések bemutatása}

Az 1. táblázat az általunk használt skálák leíró statisztikáit és a változók közötti korrelációs összefüggéseket tartalmazza.

Legelőször is megvizsgáltuk, hogy az adatok alapján összevonható-e a részleges kompenzációnak az anyagi kárpótlással, illetve a játék kipróbálásával élő esete. Ehhez ellenőriztük, hogy van-e különbség a függő változókban a két helyzetben.

1. táblázat. A vizsgált változók leíró statisztikái és a közöttük lévő korrelációs összefüggések

\begin{tabular}{|l|c|c|c|c|c|}
\hline & Átlag & Szórás & 1. & 2. & 3. \\
\hline 1. Érzelmi állapot & 3,66 & 1,42 & 1 & \multicolumn{2}{|c|}{} \\
\hline 2. Negatívumok hiánya & 5,18 & 1,30 & $0,52^{* *}$ & 1 & \\
\hline 3. Pozitívumok jelenléte & 4,93 & 1,17 & $0,48^{* *}$ & $0,65^{* *}$ & 1 \\
\hline
\end{tabular}

*** A korreláció 0,01-es szinten szignifikáns. 
Az elemzések azt mutatták, hogy egy függő változóban (érzelmi állapot: $t(218)=$ $0,73, p=0,46$; Negatívumok Hiánya: $t(223)=1,17, p=0,24$; Pozitívumok Jelenléte: $t(223)=1,66, p=0,1)$ sem mutatható ki szignifikáns különbség a két feltétel között. Az eredmények tanulsága szerint jelen esetben tehát elvégezhető ez az összevonás, de hangsúlyozzuk, hogy ez nem feltétlenül igaz minden esetben.

$\mathrm{Az}$ 1. táblázatban látható, hogy közepesen erős az összefüggés a megélt érzelmek és a megbocsátás faktorai között, ezért hipotéziseink ellenőrzéséhez MANCOVA-t alkalmaztunk. Független változóként a nemet, a jóvátételről való döntéshozót (a játék szabályzata vs. csapatvezető), illetve magát a jóvátételt (nem érkezett jóvátétel vs. részleges jóvátétel vs. teljes jóvátétel) kezeltük, továbbá azt, hogy melyik adatgyüjtésben (kérdőíves vs. laboratóriumi) vett részt a személy.

A MANCOVA eredménye szerint szignifikáns föhatása mutatkozott az adatgyüjtés formájának (Wilks- $\lambda=0,57 ; p<0,001)$, a nemnek (Wilks- $\lambda=0,94 ; p=$ 0,001 ) és a jóvátételnek (Wilks- $\lambda=0,96 ; p=0,048$ ) emellett tendenciaszintű főhatása volt a döntéshozónak (Wilks- $\lambda=0,98 ; p=0,083$ ). Interaktív hatásokat nem találtunk. A MANCOVA eredményei alapján a kezelt változók függő változókra (érzelmi állapot, megbocsátás) gyakorolt egyéni hatását vizsgáltuk.

Az adatgyüjtés módja erősen befolyásolja, hogy mennyire éreznék magukat rosszul a vizsgálati személyek $(F[1,419]=273,725 ; p<0,001)$, és hatással van a megbocsátás faktoraira is (Negatívumok Hiánya: $(F[1,419]=66,456 ; p<0,001)$, Pozitívumok Jelenléte: $(F[1,419]=77,086 ; p<0,001))$. A laboratóriumi helyzetben a vizsgálati személyek kevésbé érezték magukat negatívan, és megbocsátóbbak is voltak. Ennek oka az lehet, hogy a sérelem nem volt nagy volumenü, és egy ilyen helyzetben elképzelni a sérelmet súlyosabb negatív reakciókkal járhat együtt, mint azt ténylegesen megélni. Azonban interakcióba ez a változó semmilyen más változóval nem lépett, így feltételezhető, hogy az adatgyűjtés módja az általunk fontosnak tartott és vizsgált jelenségeket nem befolyásolja.

\section{Hipotézisvizsgálat}

H1: A teljes jóvátétel hatékonyabb, mint a részleges jóvátétel, ami hatékonyabb, mint a jóvátétel hiánya.

Az elemzések szerint az átélt érzelmek és a Pozitívumok Jelenléte esetében a jóvátétel mértéke nem mutatott szignifikáns hatást $(p>0,05$ minden esetben). Ugyanakkor a megbocsátás Negatívumok Hiánya faktorára a jóvátétel mértéke főhatást fejtett ki $\left(F_{\text {JÓVÁTÉTEL }}[2,419]=6,524 ; p=0,002\right)$, amely hatást az 1 . ábra mutatja be. A megbocsátás mértéke akkor volt a legalacsonyabb, ha nem érkezett semmilyen jóvátétel $(M=5,09 ; S D=1,41)$, a részleges illetve a teljes jóvátétel esetében a megbocsátás mértéke között nincs szignifikáns különbség.

H2: Jobban segíti a megbocsátást, ha a jóvátételról az elkövető dönt, mintha egy külső intézményes szabályozás rendelkezne róla.

H3: A második hipotézisben feltételezett fóhatás erösebben pozitív, mint negatív jóvátételi döntés esetén, de ha a jóvátételi döntés nemleges, az intézményes háttér tompithatja a személyes csalódottságot. 




Az elkövetőtől érkező jóvátételtől azt vártuk, hogy ezt követően jobban éreznék magukat a vizsgálati személyek, mint ha a jóvátételről a szabályozás dönt, de roszszabbul éreznék magukat, ha az elkövető úgy dönt, nem kompenzál. Eredményeink szerint főhatása volt annak, ki hoz döntést a jóvátételről $\left(F_{\text {DÖNTÉsHozóó }}[1,419]=\right.$ $6,01 ; p=0,015)$, de a tapasztalatok szerint a vizsgálati személyek valójában akkor érezték jobban magukat, ha a szabályozás, határozza meg a jóvátételt $(M=4,29$; $S D=1,09)$, nem az elkövető $(M=4,02 ; S D=1,08)$. Ez az érzésük független volt attól, hogy kapnának-e jóvátételt vagy sem. A 2. ábra mutatja be ezt a hatást.

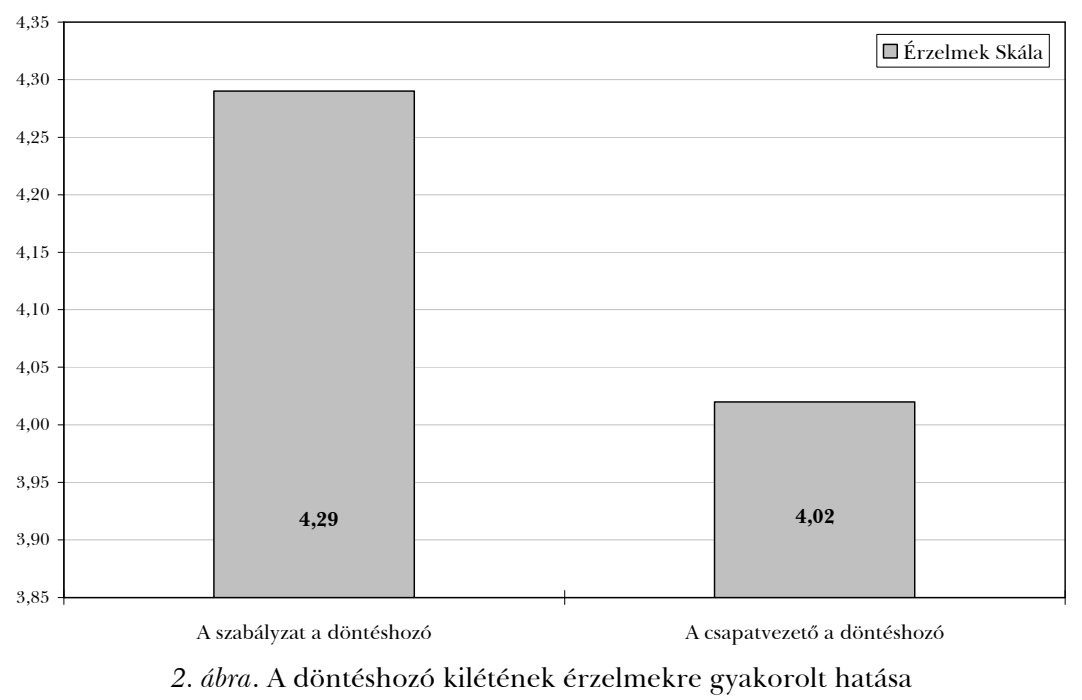


A döntéshozónak ez a főhatása a Negatívumok Hiánya esetében is megmaradt $\left(F_{\text {DÖnTÉSHozó́ }}[1,419]=5,554 ; p=0,02\right)$. Ahogyan azt a 3 . ábra is bemutatja, megbocsátóbbnak mutatkoztak azok a személyek, akiknél a szabályzat rendelkezett a jóvátételről $(M=5,52 ; S D=1,30)$, mint azok, akiknél az elkövető, azaz a csapatvezető hozta meg a döntést $(M=5,23 ; S D=1,29)$.

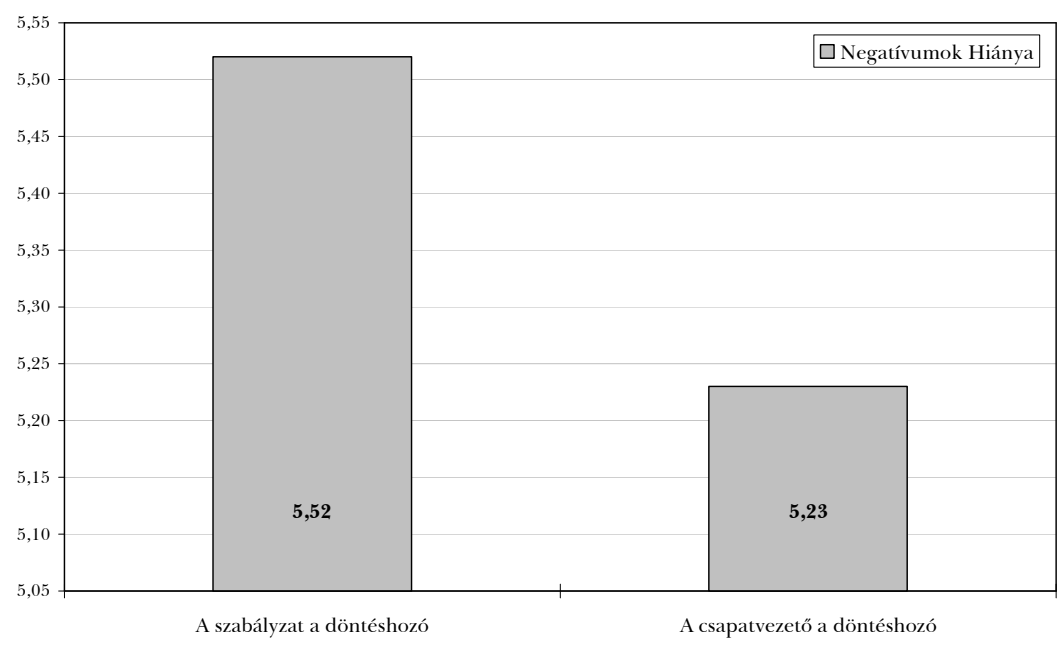

3. ábra. A döntéshozó kilétének Negatívumok Hiányára gyakorolt hatása

A döntéshozó kiléte a Pozitívumok Jelenlétére is hatott, de ez a hatás csak tendenciajellegü $\left(F_{\text {DÖNTÉSHOzó }}[1,419]=3,013 ; p=0,083\right)$. A pozitívumok nagyobb mértékben voltak jelen azoknál a személyeknél, akiknél a szabályzat rendelkezett a jóvátételről $(M=5,23 ; S D=1,30)$, mint azoknál, akiknél az elkövető hozta meg a döntést $(M=5,09 ; S D=1,29)$.

Végezetül megemlítjük, hogy a vizsgálati személyek nemének szignifikáns hatása volt az érzelmekre nézve $\left(F_{\mathrm{NEM}}[1,419]=14,836 ; p<0,001\right)$. A nők ebben a helyzetben kellemetlenebbül éreznék magukat $(M=3,94 ; S D=1,37)$, mint a férfiak $(M=4,37 ; S D=1,39)$. Más hatást a nemmel kapcsolatban nem találtunk.

\section{Az eredmények megvitatása}

A vizsgálatunk arra a kérdésre kereste a választ, hogy az elutasítást követő jóvátételnek, valamint a jóvátételi döntést meghozó fél kilétének milyen hatása van a megbocsátásra. Vizsgálatunkban a sérelem mérsékelt anyagi sérelem volt egy nem különösebben szignifikáns alkalmi ismerőstől, mely egy élménytől is megfosztotta az elutasított személyt. Természetében ez a sérelem leginkább a nem különöseb- 
ben nagy horderejü, a szervezetekben a munkavégzés kapcsán gyakran előforduló sérelmekhez hasonlítható (DE CREMER, 2010).

Első feltételezésünk nem teljesült, a teljes jóvátétel a részleges jóvátételhez viszonyítva nem hozta a tőle várt hatást, de mind a részleges, mind a teljes jóvátétel csökkentette a negatív érzéseket. Elképzelhető, hogy a sértett fél számára az a fontos, hogy kapjon valamiféle jóvátételt, ez minőségi különbséget jelent ahhoz az érzéshez képest, amikor nem kap jóvátételt. FLYNN és ADAMS (2009) a jóvátételi ajándékok esetében számoltak be hasonló jelenségről, nevezetesen, hogy az adó fél vélekedésével szemben a kapó fél engesztelődése nem az ajándék értékén múlik.

A jóvátétel nem fejtett ki hatást a pozitívumok megjelenésére. Ebből arra következtethetünk, hogy egy ilyen, nem túl személyes kapcsolatban, nem túl erős sérelem esetében a jóvátétel a sérelemből fakadó negatív érzések tompítására hivatott, de nem várható el, hogy pozitív érzések kialakulását segítse elö.

Szakirodalmi adatok alapján (Ristovski és WerTheim, 2005; DESMET, DE CREMER, és VAN DIJK, 2010) második feltételezésünk az volt, hogy jobban segíti a megbocsátást, hogy ha az elkövető a döntéshozó. Az eredményeink viszont azt mutatták, hogy kevesebb negatív érzelmet és könnyebb megbocsátást eredményezett, ha a sérelmeket követő rendezésnek intézményes keretei voltak, mint akkor, ha a rendezésért az elkövető felelt.

Ennek a jelenségnek a megkapott kompenzáció esetében a magyarázata valószínűleg a kioltási hatáshoz köthető, nevezetesen a kontrolláltság élményéhez, ahhoz az érzéshez, amikor valaki azt éli meg, hogy a másik a jutalommal irányítani akarja (FREY, 1997). Kis értékű kompenzáció esetén nagyon is megvan ennek az esélye. Ellenben az intézményes renddel kapcsolatban a „személyes” szándékok tulajdonítása valószerủtlen, hiszen ilyen esetben a sérelem rendezésének meghatározott procedúrája van. Ez a procedúra meg nem ítélt kompenzáció esetén is elfogadható, hiszen mindenkire egyformán vonatkozik, ellenben ha maga a sértő dönt úgy, hogy semmiféle kompenzációt nem ad, azzal mintegy „tetézi” a személyes interakció során elkövetett „vétségeit”.

Az eredményeink szerint a nők kellemetlenebbnek éreznék ezt a szituációt a férfiaknál, de a megbocsátás mértékében nem volt különbség. Ez nem mond ellent annak az ismert jelenségnek, hogy a nők, ha csak kis mértékben is, de megbocsátóbbak a férfiaknál (MILleR, WORTHINGTON, MCDANIEL, 2008), hiszen ha kellemetlenebbül érezték magukat a sérelem után, akkor valójában szubjektív értelemben nagyobb sérelmet bocsátottak meg ugyanolyan mértékben.

\section{A 2. VIZSGÁLAT}

Az első vizsgálatunkban a jóvátétel hatását ellenőrzött körülmények között mértük fel. A második vizsgálatunk felidézéses alapon történt, és a célja az volt, hogy megvizsgáljuk, hogy az elkövető különböző pozitív viselkedései hogyan segítik elő a megbocsátást és a kapcsolat fennmaradását egy ténylegesen megtörtént sérelem esetében. 


\section{Hipotézisek}

H1: A bocsánatkérés pozitív érzéseket, motívumokat, gondolatokat vált ki az elkövető irányába.

H2: A jóvátételtől - előző vizsgálatunk alapján - azt vártuk, hogy elősegíti a negatívumok redukcióját.

H3a: A sérelem előtti kapcsolat szorossága összefügg a bocsánatkéréssel és a jóvátétellel.

H3b: A sérelem előtti kapcsolat szorossága meghatározza a megbocsátást.

H3c: A sérelem előtti kapcsolat szorossága meghatározza a sérelmet követő kapcsolatot.

\section{Alanyok és eljárás}

Kérdőíves kutatást végeztünk, amelyben megkértük a vizsgálati személyeket, hogy írjanak le minél pontosabban egy olyan sérelmet, amit átéltek, és amelyet akkor, megtörténtük után úgy gondolták, hogy nehéz megbocsátani. Fontosnak tartottuk ezt a kikötést, mert ha ezt nem tettük volna meg, nagy valószínűséggel csak olyan sérelmeket idéztek volna fel, amelyek nem lettek megbocsátva. Ezek után a vizsgálati személyek beszámoltak a nemükről, életkorukról, és arról, hogy mikor történt a sérelem. Rákérdeztünk arra, hogy az elkövető megpróbálta-e jóvátenni a sérelmet, illetve kért-e bocsánatot. A vizsgálati személyek nyilatkoztak arról is, hogy mennyire közeli a kapcsolatuk jelenleg az elkövetővel. A vizsgált változók közötti kapcsolatokat strukturális egyenletmodellezéssel (SEM) elemeztük.

Vizsgálatunkban 111 fö vett részt, 83 nő és 27 férfi, egy személy nem válaszolt a nemmel kapcsolatos kérdésre. A minta átlagéletkora 28,01 volt, a kitöltők életkora 18 és 51 év között mozgott. A kérdőív kitöltése önkéntes alapon, névtelenül zajlott.

\section{Módszer}

Az alábbiakban bemutatjuk kezelt változókat, abban a sorrendben, ahogy a vizsgálati személyek megválaszolták a változók mérésére szolgáló itemeket. Minden esetben 7 fokú Likert-skálát használtunk, ahol az 1-es érték a „Nem értek egyet” válaszlehetőséget jelentette, a 7 -es érték pedig a „A teliesen egvetértek” lehetőséget.

A kapcsolat sérelem elötti közelsége: A sérelem elötti kapcsolat erősségének méréséhez a BERSCHEID, SNYDER és OMOTO (1989) által kidolgozott szubjektív közelség indexet vettük alapul. A kitöltők olyan állításokkal kapcsolatban formáltak véleményt, mint „A sérelmet okozó fél a sérelem elött nagyon közel állt hozzám”.

A kapcsolat jelenlegi közelsége: Hasonlóan a sérelem előtti kapcsolat méréséhez, BERSCHEID és munkatársai (1989) szubjektív közelség indexét alapul véve felmértük, hogy a vizsgálati személyek mennyire érzik közelinek kapcsolatukat a sérelmet okozó féllel. 
Bocsánatkérés: A vizsgálati személyeknek jelölniük kellett, hogy a sérelmet követően kértek-e tőlük bocsánatot, vagy sem. MCCullough, WORTHINGTON és RACHAL (1997) nyomán a bocsánatkérést nem diádikus változóként kezeltük, hanem lehetőséget adtunk a fokozatok kifejezésére is, ezért erre a kérdésre is 7 fokú Likert-skálán válaszoltak a vizsgálati személyek.

Jóvátétel: A jóvátételt, a bocsánatkéréshez hasonlóan, 7 fokú Likert-skálán mértük, hogy a vizsgálati személyek érzékeltethessék, milyen mértékben törekedett az elkövető a sérelem okozta káros hatások enyhítésére.

Megbocsátás Skála: A megbocsátás méréséhez a RYE és munkatársai (2001) által kidolgozott Megbocsátás Skálát használtuk, melynek a pszichometriai jellemzőit SZONDY (2007) tárta fel magyar mintán. Ebben a vizsgálatban nem volt indokolt az eredeti megszövegezéstől való eltérés, így az eredeti teljes skálát használtuk.

\section{Eredmények}

\section{A leirt sérelmek jellemzői}

A vizsgálati személyek által felidézett sérelmek elkövetője a legtöbb esetben a szerelmi partner volt $(21,6 \%)$, ezt követte a barát $(20,7 \%)$, illetve a szülő $(15,3 \%)$. Megielentek elkövetőként a munkahelyi vezetők (12,6\%), távolabbi rokonok $(9,9 \%)$, idegen személyek $(9,9 \%)$, munkatársak $(2,7 \%)$, tanárok $(2,7 \%)$ is. A szerelmi partner és az azonos nemű barát által okozott sérelmek túlsúlya az ilyen vizsgálatokban tipikus jelenség, máshol is megfigyelhető (például MCCullougH, ROOT és COHEN, 2006). A bemutatott történetek tartalmaztak párkapcsolati hütlenséget, bántó szavakat, elutasítást. Előfordult a szülői elhanyagolás, a szülő alkoholista viselkedése, testi sértés, lopás, rágalmazás is.

\section{Leiró statisztikák}

A 2. táblázat tartalmazza a mért változók Cronbach- $\alpha$ mutatóit, leíró statisztikákat, illetve a változók közötti korrelációs összefüggéseket. A bocsánatkérést és a jóvátételt egy itemmel mértük, ezekhez nem tartozik megbízhatósági mutató.

\section{A vizsgált változók közötti strukturális egyenlet modell bemutatása}

A változók közötti strukturális kapcsolatrendszer feltárásához strukturális egyenletmodellezést használtunk. Ez a módszer egyaránt használható egy meglévő, hipotetikus kapcsolatrendszer ellenőrzésére, illetve exploratív céllal, az adatokra legjobban illeszkedő modell kiválasztására is. A strukturális egyenletmodellezésről és pszichológiai kutatásokban való alkalmazhatóságáról bővebb áttekintést nyújt MÜNNICH és HidegKUTI (2012). Az elemzéseket az R program „lavaan” csomagjával készítettük el (RosseEL, 2012).

A kezdeti modell: Kezdeti modellünket, illetve annak eredményét a 4. ábra mutatja be. WORTHINGTON (2005) elképzeléseire alapozva a modell kiinduló pontja 
a kapcsolat sérelem előtti erőssége volt, amelytől azt vártuk, hogy meghatározza majd a sértő fél viselkedését (kér-e bocsánatot, igyekezett-e jóvátenni a sérelmet), a sértett fél negatív érzelmeit, illetve azt, hogy megbocsátja-e a sérelmet, és a jelenlegi kapcsolati erősséget is.

A fő kérdés, amire a választ kerestük, hogy a jóvátétel és a bocsánatkérés hogyan függ össze a megbocsátással, és az azt követő kapcsolati közelséggel. Mind a bocsánatkéréstől, mind a jóvátételtől azt vártuk, hogy elősegítik majd a megbocsátást, illetve a megbocsátáson keresztül segítik a felek közötti kapcsolat fennmaradását.

A kiinduló modellünk illeszkedési mutatói a következők voltak: $\chi^{2} / \mathrm{df}=4,091$, $\mathrm{CFI}=0,918, \mathrm{TLI}=0,712, \mathrm{RMSEA}=0,167, \mathrm{SRMR}=0,098$. Ezekre a mutatókra alapozva nem fogadtuk el a kiinduló modellünket, és módosításokat hajtottunk végre rajta.

2. táblázat. A vizsgálatban használt változók átlaga, szórása, megbízhatósági mutatói és a változók közötti korrelációs összefüggések

\begin{tabular}{|c|c|c|c|c|c|c|c|}
\hline A vizsgált változók & 1. & 2. & 3. & 4. & 5. & 6. & 7. \\
\hline $\begin{array}{l}\text { 1. A sérelem előtti kapcso- } \\
\text { lat közelsége }\end{array}$ & 1 & & & & & & \\
\hline $\begin{array}{l}\text { 2. A kapcsolat jelenlegi } \\
\text { közelsége }\end{array}$ & $0,56^{* *}$ & 1 & & & & & \\
\hline 3. Bocsánatkérés & $0,32^{* * *}$ & $0,47^{\text {*** }}$ & 1 & & & & \\
\hline 4. Jóvátétel & $0,31^{* *}$ & $0,47^{* *}$ & $0,67^{* *}$ & 1 & & & \\
\hline 5. Negatív érzések hiánya & $0,15^{*}$ & $0,26^{* *}$ & $0,21^{* *}$ & $0,30^{* * *}$ & 1 & & \\
\hline 6. Pozitív érzések jelenléte & $0,52^{* *}$ & $0,58^{* *}$ & $0,34^{* *}$ & $0,42^{* *}$ & $0,55^{* *}$ & 1 & \\
\hline 7. Megbocsátás Skála & $0,33^{* *}$ & $0,44^{* * *}$ & $0,30^{* * *}$ & $0,39^{* *}$ & $0,93^{* *}$ & $0,82^{* *}$ & 1 \\
\hline M & 4,81 & 3,18 & 2,47 & 2,66 & 5,14 & 3,98 & 4,75 \\
\hline SD & 2,14 & 2,31 & 2,23 & 2,16 & 1,18 & 1,49 & 1,14 \\
\hline Cronbach- $\alpha$ & 0,94 & 0,96 & - & - & 0,82 & 0,76 & 0,85 \\
\hline
\end{tabular}

**: A korreláció 0,01-es szinten szignifikáns

": A korreláció 0,05-es szinten szignifikáns

Alternatív modell: Alternatív modellünket, illetve annak eredményét az 5. ábra mutatja be. Első lépésként töröltük azokat az utakat, amelyek nem mutattak szignifikáns összefüggéseket. Meglepő módon a bocsánatkérésnek nem mutatkozott szignifikáns hatása a megbocsátás két faktorára (Negatív érzések hiánya: $\beta=$ $0,001, p=0,996$; Pozitív érzések jelenléte: $\beta=0,027, p=0,957)$. Továbbá a sérelem előtti kapcsolat szorossága nem hatott a negatív érzések hiányára ( $\beta=-0,068$, $p=0,477)$, a negatív érzések hiánya pedig nem hatott a kapcsolat jelenlegi erősségére $(\beta=-0,014, p=0,797)$.

A kiinduló modellünk modifikációs indexei azt sugallták, hogy a bocsánatkérésnek a kapcsolat jelenlegi szorosságára közvetlen hatása lehet. Mivel a bocsánat- 
kérés egy olyan viselkedés, amely a sérelem kapcsolati oldalára fókuszál (DE CREMER, 2010), ezért úgy döntöttünk, hogy indokolt a közvetlen hatás feltételezése. Az alternatív modell illeszkedési mutatói már kifejezetten jók $\left(\chi^{2} / \mathrm{df}=1,012\right.$, $\mathrm{CFI}=1,000, \mathrm{TLI}=0,999, \mathrm{RMSEA}=0,010, \mathrm{SRMR}=0,030)$.

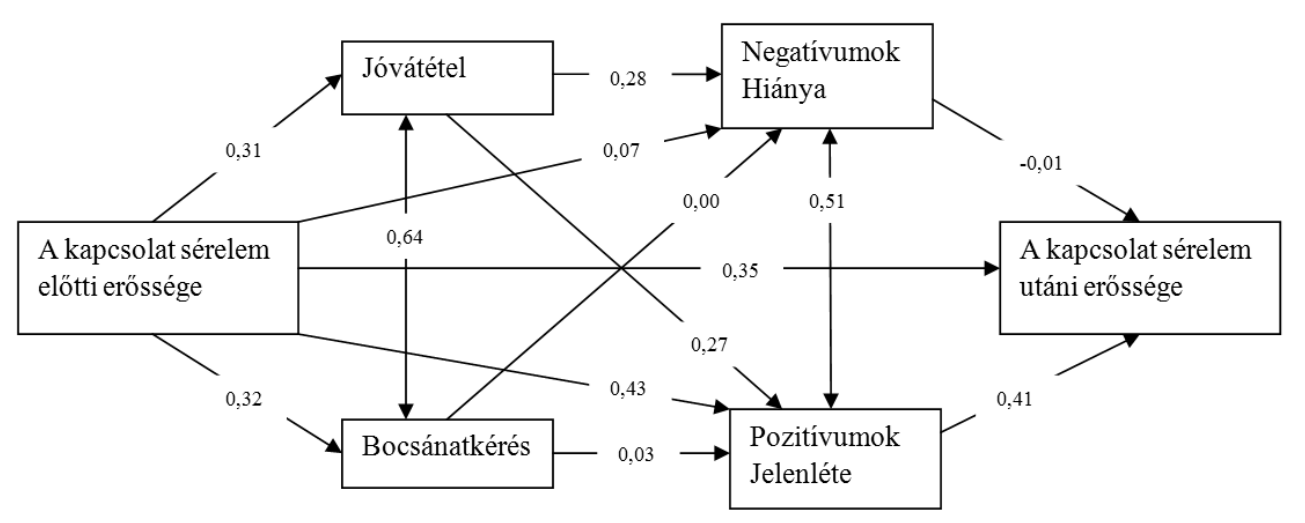

4. ábra. A kezdeti modell

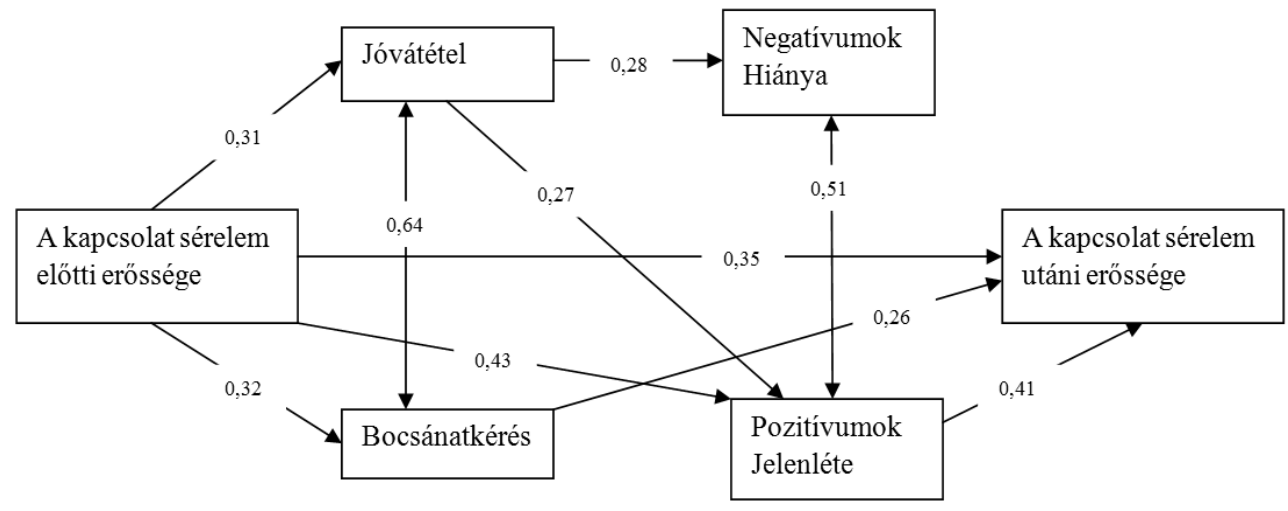

5. ábra. Az alternatív modell 
A modell eredményeinek ismertetése

A sérelem előtti kapcsolat erőssége nagyon fontos szerephez jut, hiszen a negatívumok hiánya faktor kivételével minden függő változóra szignifikáns hatást gyakorolt $(p<0,01)$. A szorosabb kapcsolat közvetlen pozitív kapcsolatban áll a felek közötti jelenlegi kapcsolat szorosságával, a bocsánatkéréssel, a jóvátétellel és a pozitívumok jelenlétével is.

A kapcsolat szorosságának hatása tehát fontos, de a mi vizsgálati kérdésünk elsősorban a bocsánatkérés és a jóvátétel megbocsátásra gyakorolt hatására vonatkozott. Ezt szemlélteti az 5. ábra. A jóvátétel a megbocsátás két faktorára közvetlenül hat (Negatív érzések hiánya: $\beta=0,28, p<0,01$; Pozitív érzések jelenléte: $\beta=$ $0,27, p<0,01)$, a bocsánatkérés viszont csak a kapcsolatra fejt ki közvetlen hatást $(\beta=0,26, p<0,01)$. Így az első hipotézisünk nem nyert alátámasztást, de a második hipotézisünk igen. A megbocsátás két faktora között meglehetősen nagy az együttjárás, ahogy nagy az együttjárás a jóvátétel és a bocsánatkérés között is. A megbocsátás faktorai közül a Pozitívumok .Jelenléte jósolta be a kapcsolati közelséget, a Negatívumok Hiánya nem mutatott szignifikáns hatást.

A bocsánatkérés közvetlen módon, pozitívan hatott a kapcsolat jelenlegi szorosságára, a jóvátétel azonban csak indirekt módon, a megbocsátáson keresztül. A megbocsátás faktorai közül a Pozitívumok Jelenléte járult hozzá a kapcsolat szorosságához, a Negatívumok Hiánya nem.

\section{Az eredmények megvitatása}

Hipotéziseink közül a bocsánatkérésnek a megbocsátással való összefüggését feltételező (H1) ugyan nem teljesült, de a bocsánatkérésnek a kapcsolat erősségével mutatkozott kapcsolata. További hipotéziseink támogatást kaptak, így a jóvátételnek a megbocsátással való kapcsolatát feltételező hipotézis (H2), s a sérelem előtti kapcsolat szorosságának a bocsánatkéréssel, jóvátétellel, megbocsátással és a sérelem utáni kapcsolat szorosságával való összefüggését feltételező hipotézisek is (H3a, H3b, H3c).

Modellünkben a sérelem előtti kapcsolat közelsége fontos szerepet töltött be. Szorosabb kapcsolatban nagyobb mértékben kértek bocsánatot, és jobban törekedtek a sérelem okozta negatív következmények csökkentésére az elkövetők. Különbséget fedeztünk fel azonban a két viselkedés hatásában. A jóvátétel közvetlenül befolyásolta a megbocsátást, de a bocsánatkérés csak a kapcsolatra fejtett ki közvetlen hatást, a megbocsátás faktoraival nem függött össze.

Feltételezzük, hogy ennek hátterében az állhat, hogy a jóvátétel konkrétan a sérelemre irányul, annak a negatív hatásait igyekszik megszüntetni, és ennek köszönhetően segíti elő a megbocsátást. A jóvátétel egy pillanatnyi egyenlegre összpontosít, a célja a sértett fél veszteségeinek az eltörlése.

Ezzel szemben a bocsánatkéréssel az elkövető a kapcsolat fontosságát fejezi ki a szenvedő fél irányába, elismeri a saját felelősségét. Ezzel kommunikálja a saját megbízhatóságát, és azt, hogy érdemes vele további kapcsolatot fenntartani. Ez 
lehet az oka annak, hogy a sérelmet követő szorosabb kapcsolathoz járul hozzá, és nem az adott sérelem megbocsátásához. A kapcsolat teljes rendeződéséhez azonban szükséges lehet a jóvátétel, mert különben a meg nem bocsátott vétség lenyomata benne maradhat a kapcsolatban, és további feszültségeket szülhet. A két viselkedés között egyébként erôs az együttjárás.

A vizsgálat fő korlátja, hogy az adatgyűjtés során felidézéses módszert használtunk. Így viszont nem feltétlenül a valós eseményeket ismertük meg, hanem a vizsgálati személyek által észlelt eseményeket és az ezekhez kapcsolódó emlékeket. Nem ismerjük az elkövetők motívumait és gondolatait, nincs közvetlen információnk arról, hogy mennyire törekedett az elkövető a sérelem jóvátételére, vagy milyen módon kért bocsánatot. Úgy véljük azonban, hogy ezzel a módszerrel megismerhetőek az egyének elvárásai egy megbocsátható és egy meg nem bocsátható helyzetről. Az egyének a tényleges sérelmes helyzetekben ezeknek megfelelően viselkedhetnek. Így ha a jóvátételnek és a bocsánatkérésnek megbocsátást elősegítő, kapcsolatfenntartó hatást tulajdonítanak az elvárások szintjén, akkor ezektől a viselkedésektől egy valós sérelem esetén is kedvező hatást várhatunk.

A két vizsgálat eredményei fontosak lehetnek a mindennapi sérelmes helyzetek kezelésében. Pozitív hozadéka lehet annak, ha a sérelmes helyzetek kezelésére van egy előzetes tervezet, amely rendelkezik a sértett fél jóvátételéről, egy szervezetben ezzel megakadályozható lehet a konfliktusok eszkalálódása. Láttuk azt is, hogy a jóvátétel önmagában nem elegendő egy szoros kapcsolatban, megfelelő bocsánatkéréssel kiegészülve azonban segíthet a kapcsolat helyreállításában.

\section{IRODALOM}

Darley, J. M., \& Pittman, T. S. (2003). The psychology of compensatory and retributive justice. Personality and Social Psychology Review, 7(4), 324-336.

De Cremer, D. (2010). To pay or to apologize? On the psychology of dealing with unfair offers in a dictator game. Journal of Economic Psychology, 31(6), 843-848.

Desmet, P. T., De Cremer, D., \& VAN DiJk, E. (2010). On the psychology of financial compensations to restore fairness transgressions: When intentions determine value. Journal of Business Ethics, 95, 105-115.

Exline, J. J., Worthington, E. L., Hill, P., \& McCullough, M. E. (2003). Forgiveness and Justice: A research agenda for social and personality psychology. Personality and Social Psychology Review, 7(4), 337-348.

FeHR, R., \& GELfand, M. J. (2010). When apologies work: How matching apology components to victims' self-construals facilitates forgiveness. Organizational Behavior and Human Decision Processes, 113, 37-50.

Fehr, R., Gelfand, M. J., \& NAG, M. (2010). The road to forgiveness: A meta-analytic synthesis of its situational and dispositional correlates. Psychological Bulletin, 137(2), 894914.

Fincham, F. D. (2009). Forgiveness: Integral to close relationships and inimical to justice? Virginia Journal of Social Policy and the Law, 16, 357-384.

FisCHBACHER, U., \& UTIKAL, V. (2013). On the acceptance of apologies. Games and Economic Behavior, 82, 592-608. 
Flynn, F. J., \& Adams, G. (2009). Money can't buy love: Asymmetric beliefs about gift price and feelings of appreciation. Journal of Experimental Social Psychology, 45(2), 404-409.

Frey, B. S. (1997). Not Just For The Money: An Economic Theory of Personal Motivation. Cheltenham: Edward Elgar.

Haesevoets, T., Reinders Folmer, C., de Cremer, D., \& van Hiel, A. (2013). Money isn't all that matters: The use of financial compensation and apologies to preserve relationships in the aftermath of distributive harm. Journal of Economic Psychology, 35, 95-107.

Karremans, J. C., \& van Lange, P. A. (2004). Back to caring after being hurt: the role of forgiveness. European Journal of Social Psychology, 34(2), 207-227.

Kearns, J. N., \& Fincham, F. D. (2004). A prototype analysis of forgiveness. Personality and Social Psychology Bulletin, 30(7), 838-855.

Kim, P. H., Dirks, K. T., \& CoOper, C. D. (2009). The repair of trust: A dynamic bilateral perspective and multilevel conceptualization. Academy of Management Review, 34(3), 401422.

Leunissen, J. M., De Cremer, D., Folmer, C. P., \& van Dijke, M. (2013). The apology mismatch: Asymmetries between victim's need for apologies and perpetrator's willingness to apologize. Journal of Experimental Social Psychology, 49, 315-324.

McCullough, M. E., Pargament, K. I., \& Thoresen, C. E. (2001). Forgiveness: Theory, Research, and Practice. New York: Guilford Press.

McCullough, M. E., Root, L. M., Cohen, A. D. (2006). Writing about the benefits of an interpersonal transgression facilitates forgiveness. Journal of Consulting and Clinical Psychology, 74(5), 887-897.

McCullough, M. E., Worthington, E. L., \& Rachal, K. C. (1997). Interpersonal forgiving in close relationships. Journal of Personality and Social Psychology, 73(2), 321-336.

Miller, A. J., Worthington JR, E. L., \& McDaniel, M. A. (2008). Gender and forgiveness: A meta-analytic review and research agenda. Journal of Social and Clinical Psychology, 27(8), 843-876.

MÜNNich Á. és HidegkUti I. (2012). Strukturális egyenletek modelljei: Oksági viszonyok és komplex elméletek vizsgálata pszichológiai kutatásokban. Alkalmazott Pszichológia, 14(1), 77-102.

Ristovski, A., \& Wertheim, E. H. (2005). Investigation of compensation source, trait empathy, satisfaction with outcome and forgiveness in the criminal context. Australian Psychologist, 40(1), 63-69.

RosseEl, Y. (2012). lavaan: An R package for structural equation modeling. Journal of Statistical Software, 48(2), 1-36.

Rye, M. S., Loiacono, D. M., Folck, C. D., Olszewski, B. T., Heim, T. A., \& Madia, B. P. (2001). Evaluation of the psychometric properties of two forgiveness scales. Current Psychology: Developmental, Learning, Personality, Social, 20(3), 260-277.

SCHER, S. J., \& DARLEY, J. M. (1997). How effective are the things people say to apologize? Effects of the realization of the apology speech act. Journal of Psycholinguistic Research, 26(1), 127-140.

Strelan, P., Feather, N. T., \& McKee, I. (2008). Justice and forgiveness: Experimental evidence for compatibility. Journal of Experimental Social Psychology, 44(6), 1538-1544.

SzOndy M. (2007). A Megbocsátásra való hajlam korrelátumai: kapcsolata a szocio-demográfiai jellemzőkkel, az optimizmussal és a boldogsággal. Pszichológia, 27(3), 221-239. 
WORThington, E. L. (2005). More questions about forgiveness: Research agenda for 20052015. In E. L. WORTHINGTON (Ed.), Handbook of Forgiveness (557-574). New York: Brunner-Routledge.

Worthington, E. L., \& Scherer, M. (2004). Forgiveness is an emotion-focused coping strategy that can reduce health risks and promote health resilience: Theory, review, and hypotheses. Psychology \& Health, 19(3), 385-405.

\title{
THE IMPACT OF APOLOGY AND COMPENSATION ON FORGIVING IN CLOSE AND DISTANT RELATIONSHIPS
}

\author{
PAPP, GÁBOR - KOVÁCS, JUDIT
}

We present two studies that aim to explore the effects of various procedural and distributive justiceelements on forgiveness. In our first study, we examined the effects of compensation on forgiveness in a questionnaire and in laboratory setting. The transgression was not severe, and the relationships between the involved parties were distant. In our second study, we used a recall method, we asked participants to write about a transgression that they found hard to forgive. According to our results compensation can promote forgiveness. We showed that the effects of compensation is influenced by who makes the decision about it: an institutional decision is more effective than a decision made by the transgressor, at least in the case of mild transgressions in a distant relationship. Compensation could promote forgiveness in a close relationship as well; however for the complete restoration of the relationship apology is also necessary. While compensation focuses on alleviating the negative effects of the transgression, an apology directly helps the restoration of the relationship.

Key words: forgiveness, institutionally and personally ordered compensation, extent of compensation 